\title{
MENTAL REPRESENTATION OF LEARNING CONTENT AND LEARNING STYLE
}

\author{
Jana Duchovicova - Nina Kozarova
}

\author{
doi: 10.18355/PG.2017.6.1.7
}

\begin{abstract}
The aim of the research was to find out the ability of students to interpret their own mental representation of the learning content from History through the mind mapping. The second aim was to find out whether the mind mapping has a positive impact on structuring the knowledge in the exposition of the learning content. The partial aim was also to compare the influence of the preferred learning style on the consistence of the mind map at the particular level of education. The authors present the results of identification of the correlation between the learner's learning style and the mental representation of the learning content through the mind maps. Particularly, it focuses on the frequency of the notions used in the maps. The authors searched for the answer whether the particular learning style (auditive, visual, kinaesthetic, and tactile) influences the mental representation of the learning content.(appeared in acquisition of notions.) The LSI Inventory by Dunn, Dunn, Price and a mind mapping test were used in the research and a chi-square test for independence was used for evaluation. 115 respondents were involved in a research group. By analysing the results we found out that the learning style has no influence on mental representation of the learning content by the learners.
\end{abstract}

\section{Key words}

learning style, preference of senses, mental representation of the learning content, mind mapping

\section{Introduction}

National and international political structures have been gradually opened towards finding different ways in education which would reflect the needs of the European future. Due to the globalization of the world, the required qualification structure has been changing, in which adaptability, independence; creativity, complexity and mobility have become the determining factors of the modern education. This requires a functioning modernization of a learning process, mainly teaching methods and strategies with the aim to move from the traditional encyclopaedism towards the systematic development of learners' critical thinking. In the recent years, the research of psychodidactic topics has become one of the important instruments of modernization, focused on the mediation context of education regarding a learner and the whole situation of education (which is a base for analysis). Monitoring the processes of transfer becomes the focus. An issue of learning or cognitive learning styles, preference for of learning styles and their relations towards effective learning or their acceptance within the teaching process, learning strategies and teaching styles belong to the psychodidactic topics. These topics have been dealt with by Mares (1998), Sternberg (1988), Felder, Henriques (1995) Felder, Silverman (1988) Felder, Brent ( 2005), Litzinger, Lee, Wise Felder (2010), Petlak, Fenyvesiova (2009), Veresova (2004), Mala (2009) etc. Other themes such as structuring the learning, analyses of learning from texts, pictures, including cognitive Slavonic Pedagogical Studies Journal, ISSN 1339-8660, Volume 6 Issue 1, February 2017 
mapping have been discussed by Pupala, Osuska, (1997), Mares (2001, 2011) and autoregulation of learning (Mares, 1998, 2001; Zimmerman, 1998; Helus, Pavelkova, 1992).

The research focuses on the existence of correlation between the preference of the learning style and consistency of the mental map expressed in the frequency of the concepts as one of the examined indicators. The paper also pays attention to explanation and operationalization of key terms such as a mind map and learning style.

\section{Mind maps in education as instruments of meaningful learning}

Learning, according to Ausubel (1967), is a process of building knowledge structure a knowledge scheme. By implementation of new knowledge, new features are subordinated to more general schemes by which the new structures and recent knowledge are enriched and changed. Joycea (2008) worked out the processes operating towards the meaningful learning, according to Ausubel. These are derivative subsumption, correlative subsumption, superordinate learning and combinatorial learning. Meaningful learning focuses on so-called expository teaching. The essential element in Ausubel's expository teaching is the advance organizer which is interpreted as an initial organizing element. This element is information (or set of informations, notions and claims) which are expressed by a teacher with the aim to help organize "newly-come" information. They are mainly used in the introductory parts of the topic and their task is to manage further progress of a learner. The advance organizers are parts of teacher's talk or learning material for learners. Veselsky (2005) states that an initial organizing element is a certain bridge between a new learning material and actual knowledge of learners because it represents initial claims and concepts related to the ideas at a lesson, as well as knowledge acquired by the learners to which the new content will be built. Ausubel distinguishes two types of advance organizers:

1. Comparative - helps learners recall original knowledge form their memory activating already existing knowledge scheme in that particular topic. The aim is to provide fluent sequence so that the learners can build their knowledge.

2. Expository - creates a primary scheme providing further information which has not been known by a learner, however, they are necessary for comprehension of a new learning content.

According to Mareas (2001) the structure of learning content as well as teacher's explanation are incomplete and not very well organized in the real practice. Basic units of learning content do not respond to the learner's age and some concepts and relations, essential for learners' comprehension, are missing.

Based on Aushubel's theory and its implementation in other studies, Grösser (2007) formulated dimensions supporting meaningful learning. Those are teacher's support in learners' engagement, enthusiasm, professional competences of teachers and subject knowledge and learners' involvement in more complicated talks, enabling educational activities by using various materials, replies to the requests for help and attention, self-reflection of teaching practice by a teacher, support for learners as active participants in the process of education and creators of knowledge structure, help for learners to reach their intellectual potential.

Novak (1998) was inspired by the theory of meaningful learning by Ausubel (1967) in creating of so-called conceptual (mind) mapping, which is a method stemming from the theory of meaningful learning.

Mind mapping is a process of creating a mind map which helps learners show relations of thoughts, concepts and words, ideas are connected with the learning content of a topic. It is also (a means of) a feedback for a teacher. Mind maps can 
serve to a teacher as information about the knowledge of a learner with a teacher should follow according to the principles of meaningful learning during the lesson. They also help in catching possible misconceptions of a learner with the aim to correct it.

Buzan (2007) reckons that until an individual can find an association between information and images, the brain creates synopses and thus helps think. Images which are caught on a mental map are interconnected and thanks to associations the brain can make such mind jumps leading towards quick understanding and rich imagination. Logic and organized connected information support a synergetic way of thinking.

The knowledge is important for school environment as well as for the field of education. All the key concepts or main ideas learners should focus on should be demonstrated visually (on the board, layout, etc.) and in the spoken explanation it is necessary to develop the concepts in parallel to the details. Thus, the right hemisphere is able to process the seen things whereby the left one can process the words. Interconnection of these two functions should contribute towards the more effective learning and remembering of the learning content.

The mind maps cannot be looked at as coloured and well-designed schemes because in teaching and learning it is not only a process of its creation. It means that an active element is important in which a learner learns through the map creation, understands correlations, thinks and that shifts him or her further. According to Mares (2001), on the one hand there are approaches towards improvement of teaching activities of a teacher. On the other hand, when we talk about learning strategies we mean processes of learner's activity improvement when selecting the learning content, its memorizing, storing in memory and further recalling with an intention of meaningful learning.

The most popular mind maps are circle maps used mainly as a tool for defining a concept or idea; then a bubble map used for description of qualities, in which a central concept is written in the middle and its characteristics are written in the side bubbles; a double bubble map is used for comparison of contrasting phenomena (subjects, persons, etc.), when determining their common and different qualities. A tree map groups thoughts or concepts into categories or groups. A flow map orders in step by step approach a certain process, event- therefore this type is used for ordering and adding particular information into a certain order as well as for identification of relations among periods or sub-periods of a certain event. A multi flow map is used for picturing causes and effects of a certain event, a bridge map is a tool for application of the searching process and showing analogies. A brace map is used for deeper analysis of the entire objects and their parts. Each of these types is different from the point of view of the difficulty and cognitive activities which are developed when learners solve them.

A concrete implementation of a mind map into teaching within individual or a group work enhances active thinking of learners. There is an activation of such knowledge processes which support meaningful learning, i.e. learning with comprehension and prevent mechanical memorization of learning content.

For illustration, Daley (2004), Swan (1997), Bahr (2004), Perusich (2010) and many others focus on mapping techniques.

The way how the concepts happen in the brain still remains unrevealed. Thagard (2001: 92) summarizes that concepts which partially respond to the words of the spoken or written communication, they are important parts of mental representation, but an idea that every concept is precisely defined can be forgotten. As well as seeing concepts as files of typical qualities due to the fact that the use of concepts lies in gaining approximate accordance between concepts and the world. A structure of 
mental ideas was discussed by e.g. Kosslyn (1994), Glasgow and Papadias (1992) Wong, Lu and Rioux (1989), etc.

Evaluation of mind maps can be considered as a positive factor. A teacher can relatively easily find out, by looking at a map, whether the learners acquired key concepts of the learning content, or whether they have understood relations between particular concepts. Mind maps can be evaluated in two ways. The first lies in a visual control which can identify the absence of certain concepts. The second is called scoring based on certain criteria which can be adapted by a teacher or a researcher in order to process them afterwards.

Tamir (1996) determined correlations as criteria for scoring (concept correlations: 1 point for correctly pictured correlation between the two concepts), hierarchies (1 point for each level but the two last levels are not counted), making new branches (1 point for each level and all other branches are evaluated with 3 points). By the sum of the points for all the evaluated categories a quantitative data is provided - the level of a mind map elaboration.In connection to significant psychodidactic activities, our ambition is to contribute towards cognitive knowledge by the research carried out in the field of learning style preference correlating with representation of the learning content caught in a mind map. We come out of the fact that if an educational activity is about to help in a child's orientation, it should contribute towards ordering thoughts and concepts which are used.

When analyzing mental maps we selected the following criteria for scoring: a key concept of the learning content, a frequency of the concepts in the map, a structure of concepts/hierarchies and consistency of a mind map. In the hypotheses of the study there are results related to the operationalization frequency of the concepts which are connected to the learning content. Those concepts from the learning content but also the interdisciplinary concepts related to the learning content but have not been mentioned, were counted.

\section{Learning style preference and its reflection in a teaching process}

A learning style is a sum, set of procedures which are preferred by an individual when learning during a certain period of his or her life. It is a specific way of learning which a learner uses in different learning situations and these procedures are not stable and can change throughout the life (Mares, 1998: 75).

Problems of styles have been studied in the world for almost four decades and they approach us through the studies and scientific papers, e.g. by Turek (2002), Kaliska (2009), Riding, Rayner (2009), etc.

Honey and Mumford (1992) have tried to develop a theory of learning styles in a commercial context and created following types of learners: an activist (is pleased from a new experience, is engaged into activities, decides intuitively, is a team player, does not like administrative work and implementation of new procedures), a theorist (focuses on ideas, plans, he/she is logical, generalizes and systematically plans, but does not trust in intuitive or social and emotional engagement), a pragmatist (is pleased with team work, discussion, debates, practical and risky applications carried by results, but he/she avoids reflection, observation and a level of deeper understanding), a reflector (focuses on understanding of concepts, uses procedures of observation, description, prediction of results (Riding, Rayner, 2009).

Entwistl (1997), Biggs (1993) represent models of learning styles based on study orientation. They have their base in phenomenological psychology and humanistic conception in which learning is considered to be a subjective issue and every human has different qualities and due to this reason they set the goal to look at the learning process through the learner and his experience, perception of phenomena and situation, approach towards learning, study results, etc. 
Theories of Dunn and Dunn (1979) are based on learning preferences. The authors focus their attention on measurement of individual preferences within the scope from the environment until the factors of teaching which influence learning of a pupil. Their learning styles reflect the ways in which five basic stimuli affect an ability to perceive, cooperate and react to a learning environment. As stated by the authors, an individual reaction determines the preferred way of learning. It will change like the factors in learning environment or in a learning process. Stimuli of environment, emotional stimuli, and sociological, physical and psychological stimuli belong to the rest of them.

Sollar (2002) in his research tried to prove relations between learning styles and school performance and it has brought a lot of interesting findings. He found the independence of preferred learning styles from a school performance of the learners. The results gained by this research thus support a potential of cognition and the meaning of intentional work with cognitive and learning style when finding the ways of how to achieve successful education and respective learning behaviour. The author thinks that this approach should be positive, focused on success and come out of recognition of individual differences within the learning context.

The studies realized in the field of learning styles focus on finding the efficiency of learning presented in the school performance in relation with the respect for a concrete preferred learning style in education. Duchovicova (2011) searched for the influence of differentiation of education based on the respect of various learning styles in English language acquisition of language categories. The author found out that the respect for an individual learning style has a positive impact on knowledge acquirement in English in the field of vocabulary and grammar.

More than twenty years ago the studies by Griggs, Dunn (1984), Smith, Renzulli (1984) proved that respecting learning styles can remarkably highten the effectivity of learning. They also point at the fact that respecting learning styles also means leaving a traditional way of presentation of the learning content, losing own teaching style, with a higher number of students involved in the educational process. Friedman and Alley (1984) also found out that a long-term disrespect of a preferred learning style can lead towards the stress and following frustration related to the subject.

A lot of authors use LSI Inventory for learning style identification. The researchers focus more on intersexual differences in learning styles, or on the impact of giftedness on learning styles.

With the help of the LSI Inventory, Cody (1983) carried out the study in which he compared learning styles of average, gifted and exceptionally gifted learners in the fifth to twelfth grade. He concluded that average learners preferred learning in warm and silent environment; they were distinguished by lower motivation for activities. The findings also point out the fact that gifted learners preferred only a reasonably warm environment and free tasks. On the contrary, the exceptionally gifted learners chose the background noise, cold environment and less structural tasks.

Cvanova (2004) identified learning styles within the focus on intersexual differences. The author proved as well as Dunn et. al (Dunn, Dunn, Price, 2004) higher preference of tactile learning of boys. At the same time, she found out that boys prefer individual learning. The girls prefer learning with their friends and their learning style is mostly auditive/visual. This research was proved also by Pelouskovsa (2006), who found out that tactile learning has the significant variable higher with boys than the girls.

Honigsfeld and Dunn (2003) state that except for the gender also other elements contribute towards learning style differentiation such as culture, creativity, age, level of school proficiency and cognitive style. In connection with the genders, they found out that boys prefer more interaction with their peers rather than learning as such. They also prefer more movement. The girls need higher temperature and they have 
a higher rate of intrinsic as well as extrinsic motivation, they prefer being accompanied when learning.

The Czech researchers Mares a Skalska (1994) focus on learning style determination and they proved the findings of Honigsfeld and Dunn (2003) valid also at the Czech schools. In their studies they found out that boys do not mind the noise and noisy background and prefer clear task structuralisation. Moreover, the authors state that girls in general prefer learning in the afternoons and evenings as a statistically significant result. The correlation between a learning style and a mind mapping has been rarely searched.

If a learner in a process of learning recognizes weaknesses and strengths, he or she can choose the most effective operation by which the best results are achieved. Therefore, every individual creates a system of behaviour when learning, which is considered to be the most effective. It is a learning style which is different by its structure, quality or a way of application and flexibility.

Our research, realized in 2015, was focused on correlation of the chosen factors of learning style (responsibility and task structuralization) and chosen categories of representation of the learning content(consistency, quality, hierarchy) identified through mind mapping. None of the followed features influenced the chosen parameter of operalization? of the mind map (consistency, quality of hierarchies). We found out that subjective mind maps of the learners and their learning styles are not significantly influenced. Regarding these results we focused on research of other factors of the learning styles.

\section{Research aims}

The subject of the research realized in 2015 was the ability of learners to interpret their mental representation of the learning content (the chosen topic was from the social and scientific subject - History) depending on their preferred learning style. Creation of mind maps becomes an evaluation instrument. The criteria for scoring were the frequency of concepts, relations, hierarches and branch making. The study presents the results of the first examined criterion - frequency of concepts.

The categories of the learning style summarize the emotional, physical, social and environmental factors which are preferred by an individual when learning and attention focusing at school. In the study we evaluate the chosen styles, namely auditive, visual, kinaesthetic and tactile (in terms of the identification instrument of Learning Style Inventory /Dunn, Dunn, Price, 2004/).

The aim of the study was to find out whether there is a correlation between the chosen factors of the learning style and mental representation of the learning content. The research problem identifies the following: What is the correlation of the learning style preference (auditive/visual, kinaesthetic, tactile) and conceptualization of learners' knowledge in History, represented by a frequency of acquired concepts. The following hypothesis is formulated from the research problem.

H 1: We assume that the preferred learning style (auditive/visual, kinaesthetic, tactile) influences the mental representation of the learning content presented in a learning performance (frequency of acquired concepts).

\section{Research Methods}

In the context of the needs of the formulated research problems the following was used:

1. The standardized Learning Style Inventory, (Dunn, Dunn, Price, 2004) was used. The Inventory focuses on preference of some factors which influence learning and are also decisive for the learning style of a learner. It summarizes emotional, physical, social and environmental factors which are 
preferred by an individual when learning and focusing the attention at school. This distinguishes him or her from their peers. By LSI Inventory examined the learning of particular learners. The inventory consists of 71 questions. The acquired results were processed by particular item coding in a way that it was formulated clearly whether a learner the given factor either 0 - does not prefer or 1-prefers.

2. The test for mind mapping was a method used for mental representation of the learning content. Before the research one lesson was devoted to creation and use of mind mapping when learning and teaching. The learning content, which had been covered during the previous lesson, was transformed into the mind map. Secondly, the learners created their mind maps from any learning content they had chosen on their own. They commented the mind map creation as easy to design but demanding for thinking. During the research the learners could write down a key word, which was analysed in detail during the lesson, anywhere in the paper. Secondly, the concepts, names, dates, years connected to the key word were joined by lines. Each learner worked on his or her mind map individually. In each class it was an unstructured form of mind mapping as the learners had not received any list of compulsory concepts but only the key word to which the structure of other concepts was necessary to make.

The learners used also verbs among the concepts (nouns were mostly used), through which they noted down the connections among the concepts on the map. Due to the reason that the key word was analysed in detail and the mind map creation happened shortly after the teaching, the focus was not only on general knowledge but mainly on testing the result knowledge acquired during the lesson. The frequency of concepts was determined for the key criterion when evaluating the maps. The factor of concept frequency is characterized as all the concepts on the map which were covered in the learning content but also interdisciplinary concepts and also the concepts connected with the topic, even though these had not been mentioned in the schooling environment (each concept was given 1 point regardless the fact whether the concept was connected directly with the learning content or it had been an interdisciplinary one. Afterwards, all the points were counted altogether and the result number was given.

3. The Chi-square test of independence was used as a statistical method for evaluation the research finding.

\section{Characteristics of the research sample}

School environment in which the research was realized was narrowed into educational environment of secondary schools/secondary grammar schools. We assume that the learners have their knowledge structure more stable. The research sample consisted of four classes, in which there were both - boys and girls. Each respondent had the same conditions for fulfilment the LSI Inventory as well as for making the mind map according to the certain topic. In order to generalize the results we tried to have the sample selection objective. We chose 115 respondents in total who attended four classes.

Table 1: Structure of a research sample

\begin{tabular}{|c|c|c|c|}
\hline Class & Learners in Total & Girls & Boys \\
\hline 2A & 29 & 20 & 9 \\
\hline 2B & 31 & 23 & 8 \\
\hline
\end{tabular}

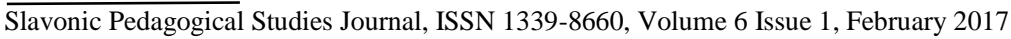




\begin{tabular}{|l|l|l|l|}
\hline $\mathbf{2 C}$ & 26 & 11 & 15 \\
\hline 2D & 29 & 13 & 16 \\
\hline
\end{tabular}

The table is used for a detailed analysis of the research sample which consisted of four classes. Apart from the number of learners there is a number of preferred learning styles identified with the help of LSI Inventory.

Table: 2 Identification of preferred learning styles of the learners

\begin{tabular}{|c|c|c|c|c|}
\hline Class & $\begin{array}{c}\text { Number } \\
\text { of } \\
\text { Learners }\end{array}$ & $\begin{array}{c}\text { Auditive / } \\
\text { Visual learning } \\
\text { style }\end{array}$ & $\begin{array}{c}\text { Tactile } \\
\text { learning style }\end{array}$ & $\begin{array}{c}\text { Kinaesthetic } \\
\text { learning style }\end{array}$ \\
\hline 2A & 29 & 24 & 2 & 3 \\
\hline 2B & 31 & 22 & 4 & 5 \\
\hline 2C & 26 & 13 & 4 & 9 \\
\hline 2D & 29 & 18 & 6 & 5 \\
\hline
\end{tabular}

\section{Picture 1: Mind map samples}

\section{Analysis and interpretation of findings}

The research focused on correlation of the preferred learning style and the learner's mental representation of the learning content through mind mapping. For evaluation of the findings a chi-square test for independence was used. The following conclusions were made.

We assumed that the concrete preferred learning style (auditive/visual, kinaesthetic, tactile) influences the mental representation of the learning content presented in the learning performance (frequency of acquired concepts).

If we follow two statistical signs we gain an idea of their dependence in the way that the research findings are ordered in a two-dimensional table. This is a table in the legend of which there are variants of one sign, and in the head there are the variants of the other sign. In particular cells there are frequencies of combinations of the both sings. These frequencies are called empirical frequencies. The left column of the table represents 0-nonpreference and 1-preference of LSI Inventory factors. In the last column of the table there are line sums and in the last line there are column sums of the empirical frequencies. In the right-bottom corner of the table there is a total sum, i.e. total number of observations. 
Table 3: Auditive/visual learning and frequency of concepts on the mind map

\begin{tabular}{|c|c|c|c|c|c|c|c|c|c|c|}
\hline $\begin{array}{c}\text { Frequency } \\
\text { of concepts } \\
\text { A/V style }\end{array}$ & $\begin{array}{c}\text { do } \\
10\end{array}$ & 20 & 30 & 40 & 50 & 60 & 70 & 80 & 90 & \\
\hline 0 & 0 & 0 & 1 & 1 & 0 & 0 & 0 & 0 & 0 & 2 \\
\hline 1 & 4 & 23 & 32 & 17 & 13 & 11 & 5 & 4 & 4 & 113 \\
\hline & 4 & 23 & 33 & 18 & 13 & 11 & 5 & 4 & 4 & 115 \\
\hline
\end{tabular}

\begin{tabular}{|c|c|c|}
\hline until 50 & above 50 & \\
\hline 2 & 0 & 2 \\
\hline 89 & 24 & 113 \\
\hline 91 & 24 & 115 \\
\hline do 50 & $\operatorname{nad} 50$ & \\
\hline 1.234783 & 0.765217 & \\
\hline 69.76522 & 43.23478 & 0.000102 \\
\hline
\end{tabular}

The sign "auditive/visual learning" and the sign "frequency of concepts on the mind map" were independent. The table of empirical frequencies was made. It showed that in several cells the frequencies were lower than 5 . Therefore, the reduction of columns and lines of the table was carried out and the expected frequencies were counted for the reduced table. The value of the testing criterion 0,000102 was counted out of the findings. This value is lower than the one from the table (3.84). The test just showed that there is no dependence among

the signs.

Table 4: Tactile learning and frequency of concepts on a mind map

\begin{tabular}{|c|c|c|c|c|c|c|c|c|c|c|}
\hline $\begin{array}{c}\text { Frequency } \\
\text { of concepts } \\
\text { in T style }\end{array}$ & $\begin{array}{c}\text { do } \\
10\end{array}$ & 20 & 30 & 40 & 50 & 60 & 70 & 80 & 90 & \\
\hline 0 & 1 & 4 & 6 & 3 & 4 & 0 & 2 & 0 & 1 & 21 \\
\hline 1 & 3 & 19 & 27 & 15 & 9 & 11 & 3 & 4 & 3 & 94 \\
\hline & 4 & 23 & 33 & 18 & 13 & 11 & 5 & 4 & 4 & 115 \\
\hline
\end{tabular}

In the table No. 3 we tested the sign „tactile learning“ and the sign „frequency of

\begin{tabular}{|c|c|c|}
\hline Up to 50 & above 50 & \\
\hline 18 & 3 & 21 \\
\hline 91 & 24 & 115 \\
\hline do 50 & nad 50 & \\
\hline 12.96522 & 8.034783 & \\
\hline 58.03478 & 35.96522 & $0.96 \mathrm{E}-05$ \\
\hline
\end{tabular}
concepts on a mind map" and they were independent. The table of empirical frequencies showed that in several cells the frequencies were lower than 5 . Therefore, the reduction of the columns and lines and the expected frequencies were counted. The value of the testing criterion was 0.96 . This value is lower than the one from the table (3.84). The test just showed that there is no dependence between the signs. 


\begin{tabular}{|c|c|c|c|c|c|c|c|c|c|c|}
\hline $\begin{array}{c}\text { Frequency } \\
\text { of concepts } \\
\text { style }\end{array}$ & $\begin{array}{c}\text { do } \\
10\end{array}$ & 20 & 30 & 40 & 50 & 60 & 70 & 80 & 90 & \\
\hline 0 & 0 & 0 & 3 & 1 & 1 & 2 & 1 & 0 & 0 & 8 \\
\hline 1 & 4 & 23 & 30 & 17 & 12 & 9 & 4 & 4 & 4 & 107 \\
\hline & 4 & 23 & 33 & 18 & 13 & 11 & 5 & 4 & 4 & 115 \\
\hline
\end{tabular}

\begin{tabular}{|c|c|c|}
\hline until 50 & above 50 & \\
\hline 5 & 3 & 8 \\
\hline 86 & 21 & 107 \\
\hline 91 & 24 & 115 \\
\hline do 50 & nad 50 & \\
\hline 4,93913 & 3,06087 & \\
\hline 66,06087 & 40,93913 & $0.73 \mathrm{E}-05$ \\
\hline
\end{tabular}

In the table No. 4 we tested the sign „kinaesthetic learning" and the sign "frequency of concepts on the mind map". They were independent. The table No. 4 tested the sign ,kinaesthetic learning“and the sign „frequency of concepts on the mind map". They were independent. The table of the empirical frequencies was made and it showed that the frequencies were in several cells lower than 5. Therefore, the reduction of columns and lines of the table was made and the expected frequencies were counted. The value of testing criterion 0.73 was counted out of the results. This value is lower than the one in the table (3.84). The test showed that there is no dependence between the signs.

90 Based on the results from particular tables (No. 3, 4, 5) we can state that a concrete learning style used by mental representation of the learning content identified by LSI Inventory, does not influence the frequency of concepts on the mind map.

From the overall interpretation of the tables it can be claimed that a subjective mental representation of the learning content by the learners is not influenced by their learning styles. It means that there must be another reason why the mind maps of particular learners of the same school year significantly differ. It would be necessary to find out more about the factors which significantly influence the mind map results. Why does one learner have a very poor mental representation of the learning content through the mind mapping whereby the second learner has the concepts structured in a logic way?

\section{Conclusion}

The aim of the research was to analyse the ability of the learners to interpret the mental representation of the content of the topic from the History subject through mind mapping regarding their learning styles on a chosen level of education. The learners at schools are in a very limited way systematically prepared for creating the structure of their knowledge on their own. Therefore, we assumed that the preferred learning style influences the mental representation of the learning content by a learner, concretely in an examined sign of the frequency of acquired concepts from the learning content. However, our assumption was not proven. The learning style has no influence on the concept acquisition, and thus on a mental representation of the learning content. The cause of the different learning performances at the secondary schools does not lie in a preferred learning style. We admit that the results may be influenced by the scope and the way of selecting the research sample or the scope of learners' representation according to particular learning styles and there can be also some other limits (e.g. uncontrollable variable such as gender or specialization of 
particular classes), however the findings are considered to be significant in a psychodidactic level.

The learning styles are discussed by a lot of researchers and a lot of Slovak, Czech and foreign studies were carried out. An empirical comparison, or proving the relation of the learning style and their mental representation of the learning content point out the fact that the learning style does not influence the mental representation of the learning content, similarly as the findings made by Sollar (2002) and the learning style does not influence the school performance of a learner.

The psychodidactic understanding of teaching based on our findings increases the need of teachers to focus their attention not on learning style reflection but mainly on the creation of cognitive structures unlike presenting information aiming towards the knowledge creation in an isolated, chaotic, scattered, non-structuralized, memorized way which is not mostly with a long-term effect and their application is usually very problematic.

In a schooling environment the learners build their individual cognitive scopes mostly based on opportunities created for them by a teacher. These are covered in a content level and a level of relations among particular content items. Learners thus acquire scientific truths in the way comprehensible for them so that they are able to describe them. Provided that the learning process is effectively managed with clear aims, learners are able to solve new situations with the help of structuralized knowledge in connection with the skills and attitudes (these are shown in their behaviour). At the same time, they are able to change, update, enrich and clarify these structures due to new experience of different kind.

In relation to the above mentioned facts, it is very important to pay attention to the issue of structuralization of the learning content and building the structure by a learner. The construction of the learning content means the optimization of learning ways and it should cover the creation of meaningful blocks with logical relations, structuralized according to their own cognition, realizing the superior concepts, their identification and limitation of relations among them, constant finding of relations to the learning content based on their own experiences and further learning and using the content in the own educational objectives.

It is important for every learner to understand the covered learning content and interconnect it with the previously acquired knowledge, work them and apply them into everyday fields of their lives. If learners knew their abilities how to structuralize their knowledge easily, not only the knowledge quality would change but also their relations to learning and to the particular subject.

\section{Acknowledgement}

This study has been written under the project: APVV-15-0368 Practice in the centre of the subject field didactics, subject field didactics in the centre of preparation for practice

\section{Bibliographic references}

AUSHUBEL D. P. 1967. Learning Theory and classroom Practice. Ontario: The Ontario Institute For Studies In Education.

BAHR. S. 2004. Bilingual knowledge (bik) maps: study strategy effects. CANAS, A. J., NOVAK, J. D. - GONZALES, F. M. (ed.): Concept Maps: Theory, Methodology, Technology. Proceedings of the First International Conference on Concept

Mapping. [online]. Pamplona, Spain: Universidad Pública de Navarra . 2004 [cit.2015-12-09].

Available online:http://cmc.ihmc.us/cmc2004Proceedings/cmc2004\%20-\%20Vol\%201.pdf 
BIGGS, J. 1993. What do inventories of students learning process really measure? A theoretical review and clarification. British Journal of Educational Psychology, vol. 63, p.3-19.

BUZAN, T. 2007. Mentální mapování. Praha: Portál, 168 s. ISBN 978-80-7367-2003.

CODY, C. 1983. Learning styles. Including hemispheric dominance: A comparative study of average, gifted and highly gifted students in grades five trouhg twelve. Doctoral dissertation, Temple University.

CVANOVA, H. 2004. Styly uceni a uzkost. Psemna prace k suborni zkousce (nepublikovana). Vedouci prace: Z. Stranska. FF MU: Brno.

DALEY, B. J. 2004. Using Concept Maps with Adult Students in Higher Education. In CAÑAS, A. J. - NOVAK, J. D. - GONZALES, F. M. (ed.): Concept Maps: Theory, Methodology, Technology. Proceedings of the First International Conference on Concept Mapping. [online]. Pamplona, Spain: Universidad Pública de Navarra . 2004, [cit. 2015.09 .15$]$ Available online:http://cmc.ihmc.us/cmc2004Proceedings/cmc2004\%20-\%20Vol\%201.pdf

DUNN, R. - DUNN, K. 1979. Learning Styles/Teaching Styles: Should They ... Can They ... Be Matched?. Educational Leadership [online]. 1979, vol. 36, no. 4 [cit. 2015-11-30].

Available online:http://www.ascd.org/ASCD/pdf/journals/ed_lead/el_197901_dunn.pdf

DUNN, R. - DUNN, K. - PRICE, G. E. 2004. Dotaznik stylu uceni. Praha: Institut pedagogicko - psychologickeho poradenstvi CR.

DUCHOVICOVA, J. 2011. Neurodidakticke poznatky v skolskej praxi. In Petlák, E. a kol.: Neuropedagogika a neurodidaktika v praxi. Nitra: UKF, s. 27-50, ISBN 97880-8094-886-3.

ENTWISTLE, N. J. (eds.) 199784. The Experience of Learning. Edinburgh; Scottish Academic Press. p.144-164.

FELDER, R.M. - BRENT, R. 2005. Understanding Student Differences. J. Engr. Education, vol. 94, no 1, pp.57-72.

FELDER R.M. - HENRIQUES, E. R. 1995. Learning and Teaching Styles in Foreign and Second Language Education, Application of the F-S learning style model to language education._Foreign Language Annals, vol. 28, no 1, pp.21-3.

FELDER, R.M. - SILVERMAN, L. K. 1988. Learning and Teaching Styles in Engineering Education. Engineering Education vol.78, pp. 674-681.

HONNIGSFELD, A. - DUNN , R. 2003. High school male and female learning style similarities and differences in diverse nations. The Journal of Educational Research. Vol. 96, no 4, pp. 195-207. Retrieved March 7, 2009, from ProQuest database.

FRIEDMAN, P. - ALLEY, R. 1984. Learning/Teaching Styles: Applying the Principles. Theory in to Practice, vol. 23, no 1, pp 77-81.

GLASGOW, J. L. - PAPADIAS, D. 1992. Coputational imagery. Cognitive Science, vol. 16, p. 355-394.

GRASHA, A. F. 2002. Teaching with style. [online]. [cit. 2015-13-11] Pittsburg: Alliance Publishers. ISBN 09645071-1-0. Available online: http://www.academia.edu/6211237/Teaching_With_Style_by_Dr._Grasha

GRIGGS, S.A. - DUNN, R. 1984. Selected case studies of the learning style preferences of gifted students. Gifted Child Quarterly. Vol. 28, no. 3, pp.115-119.

GROSSER, M. 2007. Effective teaching: linking teaching to learning functions. [online]. [cit. 2010-07-28] Available online: http://ajol.info/index.php/saje/article/viewFile/25097/20766

HELUS, Z. - PAVELKOVA, I. 1992. Vedeni zaku ke vzdelavaci autoregulaci a humanizaci skoly. Pedagogika, roč. 42, č. 2, s. 197-207, ISSN 0031-3815. 
HONEY, P. - MUMFORD, A. 1992. The Manual of Learning Styles. 3rd Ed. Maidenhead: Peter Honey. 94 s. ISBN-10- 0950844470.

JOYCE, A. 2008. Meaningful reception learning \& Schema theory. In Learning \& cognition. [online]. [cit. 2013-22-03]. Available online: http://www.indiana.edu/ p540alex/unit4.html

KALISKA, L. 2009. Koncepcia ucebnych stylov so zameranim na teoriu D. A. Kolba. Banská Bystrica: OZ Pedagóg PF UMB. 96 s. ISBN 978-80-8083-827-0.

KOHOUTEK, R. a kol. 1996. Zaklady pedagogicke psychologie. Brno: CERM s. r.o., 544 s. ISBN 80-8586794X.

KOSSLYN, S. M. 1994. Image and brain: The resolution of the imagery debate. Cambridge, Mass: MIT Press, 516 s. ISBN 0-262-11184-5.

LITZINGER, T.A. - LEE, S.H. - WISE, J.C. - FELDER, R.M. 2007. A Psychometric Study of the Index of Learning Styles. J. Engr. Education, vol. 96, no. 4 , pp. 309-319. [online]. [cit. 2016-22-03]. Available online: http://www4.ncsu.edu/unity/lockers/users/f/felder/public/ILSdir/ILS_Validation\%28J EE-2007\%29.pdf

MALA, D. 2009. Skolska matematika: ucebny styl a uspesnost. Nitra: PF UKF. ISBN 978-80-8094-592-3.

MARES, J. 1998. Styly uceni zaku a studentu. Praha: Portál, 239 s. ISBN 8071782467.

MARES, J. 2001. Strukturovanie uciva. In CAP, J., MARES, J.: Psychologie pro ucitele. Praha: Portal. 655 s. ISBN 80- 7178-463-X.

MARES, J. 2011. Uceni a subjektivni mapy pojmu. In Pedagogika, roč. LXI, s. 215247, ISSN 1338-0982.

MARES, J. - SKALSKA, H. 1994. LSI - dotaznik stylu uceni pro zaky zakladnich a strednich skol. Psychologia a patopsychologia dietata, vol. 29, no 3, pp. 248-264.

NOVAK, J. D. 1998. Learning, Creating and Using Knowledge: Concept Maps as Facilitative Tools in School and Corporations. 2. edition. Mahwah : Erlbaum, $256 \mathrm{~s}$. ISBN 0-8058-2625-4.

PEARSON, H. 2006. Genetic Information : Codes and enigmas. Nature, 444, 16. List, p. 259-261.

PELOSKOVA, S. 2004. Styly uceni a tvorivost zaku daltonskych skol. Diplomova prace. Vedouci prace: M. Stepankova. Brno: FSS MU.

PETLAK, E. - FENYVESIOVA, L. 2009. Interakcia vo vyucovani. Bratislava : Iris, 137 s. ISBN 978-80-89256-31-0.

PERUSICH, K. 2010. System Diagnosis Using Fuzzy Cognitive Maps, Cognitive Maps. In PERUSICH, K. (Ed.): InTech, DOI: 10.5772/7117. Available online: http://www.intechopen.com/books/cognitive-maps/system-diagnosis-using-fuzzycognitive-maps

PUPALA, B. - OSUSKA, L. 1997. Stimulacia ucenia deti pomocou pojmoveho mapovania. In Pedagogicka revue, roc. XLIX, č. 5-6, s. 210-218, ISSN 1335-1982.

RIDING, R. - RAYNER, S. 2009. Cognitive Styles and Learning Strategies. London: David Fulton Publish. 217 s. ISBN 1-85346-480-5.

SMITH, L. - RENZULLI, J. 1984. Learning style preferences: A practical approach for classroom teachers. Theory Into Practice, vol. 23, no.1, pp 44-50.

SOLLAR, T. 2002. Kognitivne/ucebne styly z pohladu veku a vztahu k inteligencii a skolskemu vykonu. Rigorozna praca. Nitra: FSV UKF, $126 \mathrm{~s}$.

STERNBERG, R. J. 1988. Mental self-government: A theory of intellectual styles and their development. Human Development, vol.31, pp.197-224.

SWAN, J. 1997. Using cognitive mapping in management research: Decisions about technical innovation. British Journal of Management. Vol. 8, no. 2, pp. 183-198. ISSN 1045-3172 DOI: http://dx.doi.org/10.1111/1467-8551.0050

TAMIR, P. 1996. Science Assessment. In BIRENBAUM, M., DOCHY, F. J. (eds). 
Alternatives in Assess ment of Achievement, Learning Processes and Prior Knowledge. Boston: Kluwer,

THAGARD, P. 2001. Uvod do kognitivni vedy. Praha: Portal, 232 s. ISBN 80-7178445-1.

TUREK, I. 2002. Ucebne styly a rozvoj schopnosti ziakov ucit sa. Banska Bystrica: Metodicko - pedagogicke centrum. ISBN 80-8041-423-8

VERESOVA, M. 2004. Strategie ucenia a efekty preventivnych intervencii. In Kognitivne a ucebne styly v kontexte veku a vykonu ziaka, Nitra : UKF, s. 108-135, ISBN 80-8050-712-0.

VESELSKY, M. 2005. Pedagogicka psychologia 2. Teoria a prax. Bratislava : UK, 168 s. ISBN 80-223-1911-2.

WONG, A.K.C. - LU, S.W. - RIOUX, M. 1989. Recognition and shape synthesys of 3-D objects based on attributed hypergraphs. Analysis and Machine Intelligence, IEEE Transaction on, vol. 2, no. 3, p. 279-289.

ZIMMERMAN, B. J. 1998. Developing self - fulfilling cycles of academic regulation: An analysis of exemplary instructional models. In SCHUNK, D. H., ZIMMERMAN. B. J. (Eds.): Self-regulated learning: From teaching to self-reflective practice New York: Guilford Press, pp. 1-19.

doc. PaedDr. Jana Duchovičová, PhD.

Mgr. Nina Kozárová

Department of Pedagogy

Faculty of Education

Constantinethe Philosopher University

Dražovská cesta 4

94974 Nitra

Slovakia

jduchovicova@ukf.sk

nina.kozarova@ukf.sk 